\title{
The First Steps of Emigration Policy
}

By IIRIS NIEMI

In the early days of the nineteen seventies, the extensive emigration to Sweden represented a central problem of labour policy. In Finland, an economic upswing was in progress, and more jobs than usual were available. Notwithstanding this, people in their best working years moved from the country. During the years 1969 and 1970, emigration attained its peak: during each of these years, the number of emigrants exceeded 30000 . The phenomonen was viewed with concern in our country: in the metal industry, for example, a shortage of labour power began to appear.

Speedy measures were demanded to cope with the extensive emigration. However, no foundation had been created in Finland for decisions on matters of emigration policy - quite simply, inadequate knowledge of emigration was possessed. Not even statistics on the actual scope of emigration were available. Since 1954, the mobility of labour power between the Nordic countries had been completely free, no form of working permit or other official documents were required if a move was made, and consequently no information was at hand for calculation of the number of emigrants. Accordingly, when it became a question of compiling facts on emigration, it was found that the first task was that of creating an official emigration policy for the country. As a result, in April 1970, the office of the Cabinet appointed a committee entrusted with the planning of investigations into emigration. The chairman of the committee was Altti Majava. The members of the committee consisted of specialists within various branches of science: there were representatives for social science, geography, national economy, demography and behavioural science. Furthermore, it included representatives if the Ministry of Labour Power and of the Central Association of Finnish Trades Unions. The committee had completed its report 1 by 1970: some details are given below.

The committee established that if emigration had not occurred subsequent to the second world war, the population of Finland would, instead of the current 4600000 , have been about five million. If emigration had not taken place during the course of the preceding hundred years, the population would have amounted to nearly six million inhabitants. The figures presented illustrate the compass of the emigration problem. Emigration is an essential factor which exercises an influence upon both the general population structure and the structure of labour power.

The committee concentrated most immediately upon study of the emigration from Finland to Sweden, since the major part of current emigration, or from 80 to 90 per cent, is in that direction.

The Finnish population structure in Sweden differs from both Finland's and Sweden's general population structure. For the most part, those leaving Finland are from 20 to 35 years of age. More Finnish women than men live in Sweden, and the men are more inclined to return to Finland than are the women. When

1 Sirtolaisuustutkimusten ohjelmointitoimikunnan mietintö, komiteanmietintö 1970: B 112. 
an examination is made of the professional structure of the Finns living in Sweden, it is observable that in 1960 approximately 65 per cent of them were working in industry, a percentage twice as high as that in Finland. In the service professions, there were engaged about 30 per cent of the Finns in Sweden, a figure rather less than that in the home country. Only 5 per cent of the emigrants were working on farms. The majority, or about 90 per cent of those who had moved, were living in Swedish towns. For many, the removal to Sweden had meant not only a change of the means of livelihood, but also a move into urban surroundings. Consequently, it can be assumed that the difficulties of adaptation which became evident in conjunction with removal were not solely dependent upon the new cultural environment - language, and other points - but also upon general difficulties of adaptation related to a move into a town.

When the research programme was formulated, the committee laid emphasis upon.emigration not being examined as a separate phenomenon distinct from other mobility of labour power, but that migration and emigration are parallel phenomena. The fitting in of the results of investigation presented with respect to the general social policy becomes apparent from the following scheme, which includes the main areas of the programme of enquiry.

The committee proposed investigation of the following contributory factors of migration:

- emigration, and particularly the migration towards Sweden during recent years

- immigration, and particularly the remigration of Finns resident abroad

- the situation and circumstances of Finns resident abroad, particularly in regard to Finns resident in Sweden

- internal migration, and a study of those who had remained, to the extent that this is possible, with a view to the acquisition of comparative material for investigations of emigration

The basic questions of the migration are as follows:

1. The structural requisites of the migration (the factors that cause the migratory pressure), and individual reasons (the factors that influence the decision to migrate)

2. The number of migrants and their composition. The influence exercised by the requisities for migration and the reasons upon the extent of the movement, and the classification of the migrants.

3. The influence exercised by the migration, first upon the community level, and secondly upon the individual level. The dependence of the influence upon the number of migrants and their composition. In regard to Finns resident abroad, an investigation should be made of their total and structure, along with changes in population. In addition, an examination should be made of the conditions of life of Finns resident abroad, and their adaptation to new circumstances.

In the programme of investigation, an endeavour is made to achieve cooperation between different branches of science. The programme includes studies from the aspects of geography, labour policy, economics, social policy, and cultural policy. By means of combining the results of the different results obtained in research made within the various branches of science, one should acquire a wide, complete picture of the various contributory factors of emigration, necessary in the planning of a purposeful emigration policy.

At the beginning of 1971, the cyclical movements of emigration and the dependence upon economic conditions, indicated that a large reduction had occurred in emigration. The net emigration to Sweden during the period from January to June was no more than about 1,000 persons. Accordingly, emigration appears to depend not so much upon 
personal desire to move as upon the social factors that regulate the number of emigrants. The demand for labour power diminished appreciably in Sweden by reason of the downswing in conditions in economic life. The direction of the streams of emigrants from Finland to Sweden should once again be the consequential phenomenon of the next boom in our country, unless an attempt is made to influence this conformity to law by the application of socio-political measures.
No reason exists for viewing the problem of emigration as a migration solely between Finland and Sweden: in the future, the waves of migration from Finland may also be directed towards other countries in Europe. The possible association of Finland with Europe's increasingly comprehensive economic integration can also contribute towards this, and this will mean that the emigration policy will be confronted by new and greater problems than those arising earlier. 